Itinéraires Itinéraires

Littérature, textes, cultures

\title{
Autobiography from 1998 and 2016
}

Introductory Comments: The Itinerary of Autobiography

Autobiographie, 1998 et 2016. Remarques introductives : itinéraire de

l'autobiographie

\section{Rachel Blau DuPlessis}

\section{OpenEdition}

\section{Journals}

\section{Electronic version}

URL: http://journals.openedition.org/itineraires/3661

DOI: 10.4000/itineraires.3661

ISSN: 2427-920X

Publisher

Pléiade

\section{Electronic reference}

Rachel Blau DuPlessis, « Autobiography from 1998 and 2016 », Itinéraires [Online], 2017-1 | 2018,

Online since 15 February 2018, connection on 05 May 2019. URL : http://journals.openedition.org/ itineraires/3661 ; DOI : 10.4000/itineraires.3661

This text was automatically generated on 5 May 2019.

\section{(c) $(1)$}

Itinéraires est mis à disposition selon les termes de la licence Creative Commons Attribution - Pas d'Utilisation Commerciale - Pas de Modification 4.0 International. 


\title{
Autobiography from 1998 and 2016
}

\author{
Introductory Comments: The Itinerary of Autobiography \\ Autobiographie, 1998 et 2016. Remarques introductives : itinéraire de \\ l'autobiographie
}

Rachel Blau DuPlessis

How one construes or makes an autobiography changes through one's life.

This seems like a tautology. Obvious. Of course it does! One lives more (or at least longer), and more things happen to you and around you. They have to be written up. Or written on.

But what I really mean is that, looking at your own "autobiography" as a text, your tone may change, your attitude may change from what these were when you wrote something. Even the facts of your past life may "change"-or be seen in a different light. Word choices are reconsidered. Some actual attested facts become less important; others more. Your approach to your life and what you have done changes. Your interpretation of your work and of your acts may alter or modify. Your past angers or unhappiness may change in the present or erode in importance. You have other things, new or old, to emphasize and new judgments of the things you might hide or elide. Even the gaps change. The erasures change or might re-emerge as writing rather than erasures. All this boil-up presents formal problems, emotional issues, literary propulsions.

4 Therefore even if you simply write one autobiography, there is not one of these documents but several, even if some are only latent, inside your consciousness or articulated by your best judgment. These texts or drafts or attempts at autobiography gloss each other. Your motivation and intention are always at the ready-it is your life, after all, and perhaps you can go back into an autobiographical text and modify or expand.

5 This is what I have done here with this doubled text, two writings just under twenty years apart: 1998 and 2016. One is a letter in poem form, virtually unchanged. The other, carefully dated is something I wrote for this journal. Thus I have articulated a palimpsestic layering of autobiography itself in form, here, by doubling and glossing something I wrote in 1998 . How was the original written? It was a text, possibly unsent, to 
someone who asked a question of me-I think it was something like "is your work postmodern?" It is actually epistolary, and also in lines. This text creates itself and makes a structure via layering.

6 1998. Dear M

dear Mn

dear near Mn (can't remember how to spell

that Greek mother of the muses, she of embarrassing

memory, the way any girls of 14

hate that sexy farting mother)

God, do you have to?

that element Mn

that flare of Magnesium is it?

no, try Manganese, number 25, a grey-white

brittle metal

added to others increases harness

and can increase magnetism)

this is for you. And

Mnosyneme. (I looked it up.)

$=$

7 2016. As for the postmodern

I am agnostic.

Sometimes I believe it, sometimes not.

Is it a term adequate to our time?

The argument for a material break-computers, globalization,

micro-sorting and data-slotting,

the tabs "they" can keep on me-they know

what catalogues to send me but

oh they cannot know

(or so I say)

how to make me buy

and so I glumph around

often in certain

Quaker-style old clothes

in my quasi-Quaker town,

whose faded, principled

[unacknowledged upper] middle classness

of sometimes patronizing caritas

is hard to face (even as one rejects it)

given the circulation of objects to buff you up,

bread machines and such, while the poorest

cities in the U.S., Chester, PA and Camden, N.J.

are quite near.

8 2016. That consumerist imperative

netted many people, to my shock. 
Don't they see through it? See through the chemical foods? Now there's the purge-all involved with the personal body, with private life. The country's first bulimic in bulk, people waddle, stuffed without nourishment, then there's the purge: purge your house, purge your possessions, purge your stomach.

It is a set of bodies sickened by their own engorgement with the lies that power has fed them for let's say, the past 18 years.

The body politic? a rancorous community filled with resentments, caught in an almost invisible net.

1998. Post-modern?

Why do I resist going along?

Postmodern is so convenient! My work will never be consumed If I can't join some rubric.

10 Groucho Marx-why don't you look away so I can settle into a club that wants me!

11 1998. But

I think I would like to begin the modern all over again.

A modern, a real modern, with new arrangements of gender, and the erasure of "color lines" (as DuBois said)-color liens and color liesand the mocking and erosions of nationalisms (as at least Woolf said, holding for the cosmopolite), the impossibility of genocides and no kids holding guns, no kids in the mines, no kids dredging garbage, no wrecking of the landscape by extraction, no non-vaccinated people with curable diseases and

12 ideally people working in the morning and then dancing (in public or private) later and into the night with insomnias of joy and not the rigid sleeplessness of dread or anguish

13 sustainable sharing the revolution of fairness and justice once alive, promising, in the air. 
14 Why

was that too much to

ask?

2016. The list got longer in twenty years.

I'd have to add fracking, and the 2008 Economic

Crash

caused, manipulated, but still unpunished.

SAVE SCHOOL NOT BANK

was the graffito I saw in a foreign country.

I'd have to add random terrorist murders, here and there,

randomized but not, finally, random,

fanatics of various kinds, almost, it must be noted, almost all male;

erosions of trust, trashing of civility,

femicides of possession-very common-rape within war

and rape as punishing control in what is called

normal life.

I'd have to add jailing populations of color,

the war coming home and the war exported; dialectics

of anger

egging each other on-we are now down the path

to social militarization; and

in this climate to write poetry, it seems nothing

more startling

to try

to do

and why?

because I need to, but not to decorate my age

or to invent allegories around little observations

or even to evoke a spiritual realm,

particularly-

I think transcendence is often much too easy

to fall into

and I have,

but the realm of poetry needs also to be

grainy,

and against its own grain.

To want

just a realm of the real, or the possible

but now it is hard to know

exactly how

16 to try

to do

and what my "need" is to do this.

(Yes, something about language, something about ethics.

Attentiveness and empathy.) 
My aesthetic crisis is my political crisis.

Currently unresolved.

17 2016. And coincidentally worse

the next day from when I wrote the above, the day of July 8, 2016,

when, after 2 police murders of black men

in that very week,

a suspect (with others), sniper fired

on Dallas police guarding a peaceful

Black Lives Matter

demonstration,

and killed (at this count) five policemen.

$18 \quad 1998$.

I was spoiled politically by the up-moment

of U.S. feminism, and

other movements: anti-war and civil rights-

these claims for social justice.

Turn the machine around.

Build another society.

Big time did I miss the boat.

They have named another monument after Reagan.

Over the next thirty years

people roused as me

will die off,

and no one will remember

or they will think it very quaint.

19 That we thought

it mattered.

But while I am alive, I claim another modern

the modern that should have been

social justice, gender justice

the adjudication of conflicting issues

21 a modern verso, turn back against much of what is, capitalist depredation, oligarchic depredation,

exploitation and ruin, and

make that running line of verse turn and evoke

insist on the turn of what could have been

different.

22 So without memory, with a bad memory,

with the repressions of memory,

I resist amnesia. 


\section{is total.}

"The whole

is what is untrue"

has certainly been my motto.

Fragments remain.

Remain fragments.

Inside the poetics are

other poetics, other poets.

24 We want clarity,

but even when clear

we seem hermetic.

25

26

Splits, flakes, bursts

his green glass gone smash

on the rooftop

27 he makes it gleam

but sometimes nothing gleams.

28 For me-that mirror

silver

face up in the asphalt

at $10^{\text {th }}$ and Berks

by the projects.

29

\section{that as so gleaming.}

"The Projects"

30 when as a [white] child I first heard

that word, I heard

"the projex"

31 with the sounded hex and the rhyming rejects.

32 1998. Essay is for me

resistance to totality.

My place for vector,

for letting go-my kind

of "composition by field."

A loosening of something let

loose. A romp of thinking.

The place where the one-two step dance

of thesis-antithesis

is perpetually open,

for synthesis zooms and doesn't

settle. Synthesis

is the most unstable,

a half-particle formed under pressure 
in cyclotronic imaging

spinning to its micro-timed

demise.

1998/2016. It was me who suggested

that the French translation

of four Drafts done at

Royaumont be called

"essais" and not "brouillons"

34 and it was.

And then on the long-awaited cover (a photo done by Hocquard of a pile of trashed books-which was my instruction and my desire)

35 I saw that essais

made a partial anagram of DuPlessispart of my name.

Onomastics

are the gymnastics of agency:

otherwise

why would the doctor

who wanted to make his mark by human

cloning

be named Dr. Seed,

and why would it have been

Kadish

of Lithuania who clandestinely

photographed the Jewish ghetto

on the very verge of what

he knew

was to be

annihilation.

36 2016. These examples

could be multiplied.

37 And the translation of twenty Drafts

that appeared in French in 2013

by Auxeméry

done by Corti

is called Brouillons.

It incorporates the work of "Essais."

2016. Who can place

one's own work? Isn't it enough

just to get it done?

No. Not today. There is a very well-sharpened

machinery of reception- 
self-stardom, publicity,

superficially grateful and endlessly

stagy, thanking people for

the opportunity

to give even more presentations

of one's exquisite self.

"I write my autobiography every day"

"on Twitter and on Facebook."

"Important to claim airtime, let people know"

"otherwise you'll be ploughed under."

Hence "we're"

always investigating and

talking about

our extraordinary insides and our

oh so happily rewarded accomplishments.

The examination of conscience

now sparkles with bling!

40 And of course by a certain age

one knows plenty of dour jealous people

who did not ever get "enough."

Because there is no "enough."

Repletion fails us; there is no stop.

41 It's an odd thing, at this juncture,

to write in the zone of

autobiography.

With the claim "modestly."

Impossible?

42 You have to assume erasures,

half-truths, repressions,

and some narcissism

no matter how assiduously

these are denied, or

simply unmentioned.

43 1998. To return to your question.

I have spent much time

in the "between."

[2016: I still do.]

44 I see the other side. I see and resist.

If someone says "feminist," I will say

"post-structuralist."

And then to anything else (post-modern?)

my rejoinder will be "feminist."

[2016: this was not always popular,

to say the least. When Ann Snitow and I

finally published The Feminist

Memoir Project-precisely 1998-that we had so 
laboriously edited and with so much intellectual love, it looked like the nadir for that concept (gender justice) and its positions and actions and stances.

oh.]

From 1968 to 1988 (this being a nice round date)

my poetry

was too feminist for the objectivists

and too objectivist for the feminists.

Now, or circa 1988 to 1998 ,

sometimes Ron Silliman lets me know

almost without saying it (such is his affect)

that my reception is coat-tailing

on Language Poetries

so why don't I just "go to hell," as Huck Finn would say

and admit it.

I agree, I agree, I cannot exactly disagree-

his perspicacious beam on literary history

is pretty lucid.

All too well I see

the contours of reception and the places

one "takes up" with one's jostled "subjectivity,"

47 (2016) but mine included Montemora (that brilliant

internationalist journal of objectivist clarities

which was a great help in many particulars-

one might even say exemplary-and where my name once appeared on the

same cover with Jabès and my happiness was for that moment

complete)

and Sulfur (a place where my defection from the expressionist,

the surrealist, and the graphically embodied did not preclude

my actually appearing there and being encouraged by

being there)

49 and being part of the editorial collective

of Feminist Studies, not only an "academic journal"

but founded in someone's closet

just yesterday fifty years ago, and

one whose central struggle was to make gender

analyses part of vital and respected intellectual life. So this journal

to which many people devoted many often thankless hours

was part of the explosive paradigm shift

that feminist thinking

propelled, and this was something I did for fifteen years

(to speak of "autobiography").

50 All this

all at the same time.

51 Plus, critically, (and along with a brave cohort of

other women) 
I was reading women writers and

writing about them-which was then an easy path

to professional suicide.

52 Until, that is, the paradigm changed enough

precisely because (agency-alert) of our struggles,

and the hot air went out of certain

canon-shaped balloons.

I was "going to hell" twenty ways come Sunday.

It was lively enough.

54 So as for Language Poetry-admirable if, in their seed-time

sometimes a bit rough-shod on the issues of gender, I was not there and got only interesting scintillations of its formation and formulations.

In many ways, Thomas Kuhn

had already been enough-

I read it in 1971. Yes!

However, (1998/2016) it's true I was parallel

to Language Poetries (perhaps we both had read

The structure of scientific revolutions)

in the critique of consciousness, of cultural forms,

and of ideology,

in the resistance to the institutions of Poetry,

in interests in the histories of avant-gardes,

and in the uses of modernisms

and finally in the perpetually perplexing question

in the literary and political zones-though these are

not exactly the same-

What Is To Be Done?

57 So while I see parallels to my now engaging

Language Colleagues

(you know who you are)

I'd say somehow I got there

all by myself

in isolation in Lille, France and in Swarthmore, PA

in the years 1971-1988

mainly by myself (there were also Frances Jaffer,

Beverly Dahlen, and Kathleen Fraser,

epistolary companions).

By myself with all the uncorrected intellectual errors

the lack of social skills (for negotiating groups)

and the awkwardness

that you see so visible here.

I wanted "re-vision" without cease; I even wanted more

than Adrienne Rich might have allowed in her

changing definitions of what that would entail

(i.e. with men or without them). 
I want permanent unfinishable dialectics.

I want an endless repositioning, with ethical qualification.

I can see the many paths (though of course not all of them).

The term for this is "negativity."

\section{AUTHOR}

\section{RACHEL BLAU DUPLESSIS}

Professor Emerita, Temple University (Philadelphia) 